\author{
RESEARCHPAPER
}

\title{
Yield advantages and nutritional security of farming communities by adoption of technological interventions under pulses
}

\author{
R.K. SINGH ${ }^{1}$, R. NAYAK ${ }^{1}$ AND S.K. YADAV ${ }^{2}$ \\ Krishi Vigyan Kendra, Kotwa, AZAMGARH (U.P.) INDIA \\ Krishi Vigyan Kendra (NDUAT) FAIZABAD (U.P.) INDIA \\ Email : rksagron@gmail.com
}

Article Info :Received : 28.12.2015; Revised : 14.01.2016; Accepted : 12.02 .2016

Uttar Pradesh is the second largest producer accounting for about 16 per cent of total production. The area, production and productivity of pulses in UP including district Azamgarh is quite low as compared to other states in respect of national acreage and production. Among various constraints, poor crop management and protection technologies assume primary position. Considering the facts of low yield of pulses due to technological gap and various other constraints, Krishi Vigyan Kendra, Azamgarh of Uttar Pradesh conducted front line demonstration consequently five years on improved agricultural technologies of pulses i.e. pigeonpea, chickpea, field pea and lentil in scientific manner at farmers' field during 2008-09 to 2012-13. A total of 241 demonstrations of pulses were conducted in an area of 90.0 hectares. The results of five years under front line demonstration on pulses revealed that the average grain yield of pigeonpea $(19.1 \mathrm{q} / \mathrm{ha})$, chickpea $(19.1 \mathrm{q} / \mathrm{ha})$ field pea $(23.5 \mathrm{q} / \mathrm{ha})$ and lentil $(17.8 \mathrm{q} /$ ha) with their 56.5, 43.6, 40.8 and 45.1 per cent increase in yield over farmers practice were recorded under demonstration plots. Implementations of improved technological interventions in all demonstrated crops were also found remunerative in terms of B: $\mathrm{C}$ ratio over existing practices. The enhanced yield achieved through adoption of improved production and protection technology in pulses maintain the soil health, incremental sustainable development in production, enhancing nutritional securities and improves the livelihood of the farmers. The outcome of the trial inspired the farming communities to replace their old nondescriptive varieties with resistant and high yielding varieties and other production and protection related technological options which are being cultivated.

Key words : FLDS on pulses, Grain yield, Food, Nutritional security

How to cite this paper : Singh, R.K., Nayak, R. and Yadav, S.K. (2016). Yield advantages and nutritional security of farming communities by adoption of technological interventions under pulses. Asian J. Bio. Sci., 11 (1) : 146-150 [Special Issue of AFBSAH-2016]. 